\title{
An analysis of scientific activities in the first year of the COVID-19 pandemic
}

\section{COVID-19 Pandemi"nin illk yılındaki bilimsel faaliyetlerin analizi}

\author{
Koray Baș ${ }^{1}$ Fullya Yillmaz ${ }^{2}$
}

'İzmir Bakırçay University, Faculty of Medicine, Department of General Surgery, İzmir, Turkey

${ }^{2}$ University of Health Sciences Izmir Bozyaka Training and Research Hospital, Department of Anaesthesiology and Reanimation, İzmir, Turkey Corresponding author:Fulya Yilmaz, MD, University of Health Sciences Izmir Bozyaka Training and Research Hospital, Department of Anaesthesiology and Reanimation, İzmir, Turkey

E-mail: fulya.dr@gmail.com

Received/Accepted:July 14, 2021 /September 29, 2021

Conflict of interest: There is not a conflict of interest.

\section{SUMMARY}

Objective: COVID-19, a contagious disease which is caused by novel coronavirus (SARS-CoV-2), is still spreading globally. Bibliometric analyses assess the current status and trends in a spesific research domain by using several (Scopus, PubMed, Web of Science) databases. The aim of present study is to evaluate the scientific activities in the first year of the COVID-19 pandemic on scientific output.

Method: Web of Science software was used for the search and the analysis. All scientific papers published about COVID-19 included in Science Citation Index Expanded (SCI-E) from January $1^{\text {st }}$ to December $13^{\text {th }} 2020$; the date of the study, were searched by using the terms of "COVID-19", "2019-n-CoV", "SARS-CoV-2", "Coronavirus disease 19" and "2019 novel coronavirus" as scientific nomenclatures of COVID-19 in the topic search section of the software.

Results:Overall; 47368 scientific papers related to COVID-19, indexed by SCI-E, were found related to COVID-19 between January 1, 2020 to December 13, 2020. The biggest contribution for publications was from United States of America, the most of the publications was articles, the authors that contribute to the literature $\geq 150$ papers were all from China and the journal that published the most paper was British Medical Journal. Conclusions: The present analyse reports an overview of the literature on COVID-19 since the beginning. These kind of periodic analysis provides interesting insights regarding the past and progress of each area of scientific knowledge and also can guide the rethinking of scientific data.

Keywords: COVID-19, 2019-n-CoV, SARS-CoV-2, Coronavirus disease 19, 2019 novel coronavirus
Koray Baş

(D) Fulya Yilmaz

ORCID IDs of theauthors: K.B. 0000-0001-7911-0218 F.Y. 0000-0002-6901-7404

\section{ÖZET}

Amaç:Yeni koronavirüsün (SARS-CoV-2) neden olduğu bulaşıcı bir hastalık olan COVID-19 hala küresel olarak yayılıyor. Bibliyometrik analizler, çeşitli (Scopus, PubMed, Web of Science) veritabanlarını kullanarak belirli bir araştırma alanındaki mevcut durumu ve eğilimleri değerlendirir. Bu çalışmanın amacı, COVID-19 salgınının ilk yılındaki bilimsel faaliyetleri bilimsel çıtı üzerinden değerlendirmektir.

Yöntem: Arama ve analiz için Web of Science yazılımı kullanılmıștır. 1 Ocak - 13 Aralık 2020 tarihleri arasında Science Citation Index Expanded (SCI-E) kapsamındaki COVID-19 hakkında yayınlanan tüm bilimsel makaleler; Web 
of Science yazılımının konu arama bölümünde COVID-19 ile ilişkili "COVID-19", "2019-n-CoV", "SARS-CoV-2", "Coronavirus hastalı̆̆1 19" ve "2019 yeni koronavirüs" terimleri kullanılarak arandı.

Bulgular: Genel olarak; SCI-E tarafindan indekslenen COVID-19 ile ilgili 47368 bilimsel makale, 1 Ocak 2020-13 Aralık 2020 tarihleri arasında COVID-19 ile ilișkili bulundu. Yayınlara en büyük katk1 Amerika Birleșik Devletleri'nden geldi. Tüm yayınların çoğunluğunu makaleler oluşturmaktaydı. Literatüre $\geq 150$ makale ile katkıda bulunan yazarlar Çin'dendi. En çok yayın paylaşan dergi ise British Medical Journal'du. En çok makaleyi yayınlayan dergi oldu.

Sonuç: Mevcut analiz, başından beri COVID-19 ile ilgili literatüre genel bir bakış sunmaktadır. Bu tür periyodik analizler, her bilimsel bilgi alanının geçmiși ve ilerlemesi hakkında ilginç bilgiler sağlar ve ayrıca bilimsel verilerin yeniden değerlendirilmesine rehberlik edebilir

Anahtarsözcükler: COVID-19, 2019-n-CoV, SARS-CoV-2, Koronavirüs hastalığı 19, 2019 yeni koronavirüs

\section{INTRODUCTION}

COVID-19, a contagious disease which is caused by novel coronavirus (SARS-CoV-2), is still spreading globally ${ }^{1,2}$. SARS-CoV-2 is a spherical, enveloped, positive-sense, single stranded, RNA coronavirus. It belongs to the order Nidovirales and genus of $\beta$-coronavirus of Coronaviridae family ${ }^{1,3}$. The first COVID-19 case was emerged in late December 2019 in Wuhan, China and on $11^{\text {th }}$ March, 2020 World Health Organization (WHO) declared COVID-19 as pandemic ${ }^{1-4}$.

Bibliometric analyses assess the current status and trends in a spesific research domain ${ }^{5}$ by using several databases (Scopus, PubMed, Web of Science) ${ }^{4,6}$. There are a few bibliometric studies that analyzed worldwide data in the literature ${ }^{2,7}$. All of them had analyzed the scientific reactions in the first half of the pandemic so none of them has been evaluated a wide number of papers as in this search.

The aim of present study is to evaluate the scientific activities in the first year of the COVID19 pandemic on scientific output.

\section{MATERIAL AND METHODS}

Web of Science (WoS) software, which is a popular database for data extraction for bibliometric analysis ${ }^{4}$, was used for the search and the analysis. Ethics Committee Approval is not necessary for this kind of analysis. To analyse scientific productivity of all scientific papers published about COVID-19 included in Science Citation Index Expanded (SCI-E) from January $1^{\text {st }}$ to December $13^{\text {th }} 2020$; the date of the study, were searched by using the terms of "COVID-19", "2019-n-CoV", "SARS-CoV-2", "Coronavirus disease 19" and "2019 novel coronavirus" as scientific nomenclatures of COVID-19 in the topic search section of the software. We applied an "Advanced Search" by using search operators as AND, OR and NOT to reduce the risk of overlapping of papers in this time span. We further analyzed these results by the "analyze" function of the software in terms of number of publications up to the date of the study, web of science categories, contribution of authors, name of journals, types of documentations and number of papers for each country. And also we searched "With how many publications did countries contribute to the top 5 publication types" and "With which publication types did top 5 countries contribute to the literature".

\section{RESULTS}

Overall, 47368 papers, indexedby SCI-E, werefoundrelatedto COVID-19 betweenJanuary 1, 2020 toDecember 13, 2020. Interms of specialities, accordingtosciencecategories of WoSdatabase,

themostcontributionwasfromMedicine General Internal $\quad(n=6443), \quad$ followed by PublicEnvironmentalOccupationalHealth $(\mathrm{n}=3525)$, InfectiousDiseases $(\mathrm{n}=2831)$, Surgery $(n=2406)$ andImmunology $(n=2122)$. Regarding numbers of each authors' contributions, Wang Y $(n=207)$ was ranked first row, Wang $J(n=192)$ was ranked second raw, Zhang $\mathrm{Y}(\mathrm{n}=186)$ was ranked third row, Liu $\mathrm{Y}(\mathrm{n}=176)$ was ranked fourth row and $\mathrm{Li} \mathrm{Y}(\mathrm{n}=169)$ was ranked fifth row in the list. Other authors' publication counts were $\leq 165$. Top 10 journals that published over 250 papers were British Medical Journal $(\mathrm{n}=1109)$, Journal of Medical Virology $(\mathrm{n}=707)$, International Journal of EnvironmentalResearchandPublicHealth $(\mathrm{n}=573)$, Lancet $(\mathrm{n}=423)$, Plos One $(\mathrm{n}=403)$, JAMA Journal 
of TheAmericanMedicalAssociation $(\mathrm{n}=378)$, New EnglandJournal of Medicine $(\mathrm{n}=274)$, International Journal of InfectiousDiseases $(\mathrm{n}=268), \quad$ Critical Care $\quad(\mathrm{n}=265)$ andSubstainability $(\mathrm{n}=250)$ (Table 1).

The types of publications were mostly articles $(44.51 \%)$ and followed by letters (20.67 \%), editorial materials $(18.38 \%)$, earlyaccess (12.48 $\%)$ and review (10.81\%). Other publications' percentages of contribution were under $10 \%$ (Table 2). Regarding numbers of countries contributions, The United States of America (USA) was ranked first row for all types of publications. Peoples R China (PRC) rankedsecondrowforarticleandreview;

thirdrowforletterandearlyaccessandfourthrowfored itorialmaterial.

Italyrankedsecondrowforletterandearlyaccessandt hirdrowforarticle, editorialmaterialandreview. Englandrankedsecondrowforeditorialmaterialandf ourthrowforarticle, letter, earlyaccessandreview.
Whenwelimitedouranalyzeresultsto top countriesforthecontributionstopublications;

Indiacontributedwithletter, earlyaccessandreview; Germany

andCanadacontributedtopublicationsonlywitharticl eandeditorialmaterialsrespectively (Table 2). Publications were dominantly in English $(\mathrm{n}=46133)(97.39 \%), \quad$ then in Spanish $(\mathrm{n}=417)(0.88 \%)$, German $\quad(n=414)(0.87 \%)$, French $(\mathrm{n}=229)(0.48 \%)$ and Portuguese $(\mathrm{n}=66)(0.13 \%)$. The number of papers published with languages of other countries were $\leq 50$.

In this period, the biggest contribution was from USA $(29.09 \%)$, and followed by PRC (14.53\%), Italy $(11.63 \%)$, England (10.22 \%), and India $(5.06 \%)$. Other countries' percentages of contribution were under $5 \%$. Top 5 countries contributed to the literature with article. While PRC, Italy and India shared second row for letter; USA and England shared second row for editorial materials (Table 3 ).

Table 1: COVID-19 researchesfromJanuary 1 toDecember 13, 2020

\begin{tabular}{|c|c|}
\hline Termsusedforanalysis & $\begin{array}{l}\text { "COVID-19", "2019-n-CoV","SARS-CoV-2", } \\
\text { "Coronavirusdisease 19","2019 novelcoronavirus" }\end{array}$ \\
\hline Number of publications & 47368 \\
\hline \multirow{5}{*}{$\begin{array}{l}\text { Web of sciencecategories } \\
\text { (Contribution } n \geq 2000 \text { ) }\end{array}$} & Medicine General Internal $(n=6443)(13.60 \%)$ \\
\hline & $\begin{array}{l}\text { PublicEnvironmentalOccupationalHealth }(\mathrm{n}=3525) \\
(7.44 \%)\end{array}$ \\
\hline & InfectiousDiseases $(\mathrm{n}=2831)(5.97 \%)$ \\
\hline & Surgery $(\mathrm{n}=2406)(5.07 \%)$ \\
\hline & Immunology $(\mathrm{n}=2122)(4.48 \%)$ \\
\hline \multirow{8}{*}{$\begin{array}{l}\text { Contributerauthorswithstudiesoverthenumber of } \\
\qquad 150\end{array}$} & Wang Y $(n=207)$ \\
\hline & Wang J (n=192) \\
\hline & Zhang Y (n=186) \\
\hline & Liu Y $(n=176)$ \\
\hline & $\operatorname{Li} Y(n=169)$ \\
\hline & Liu J $(n=165)$ \\
\hline & Zhang L ( $\mathrm{n}=153)$ \\
\hline & Wang $\mathrm{L}(\mathrm{n}=150)$ \\
\hline \multirow{10}{*}{ Top 10 journalsthatpublishedthepapers } & British MedicalJournal $(\mathrm{n}=1109)$ \\
\hline & Journal of MedicalVirology $(n=707)$ \\
\hline & $\begin{array}{l}\text { International Journal of } \\
\text { EnvironmentalResearchandPublicHealth }(\mathrm{n}=573)\end{array}$ \\
\hline & Lancet $(n=423)$ \\
\hline & PlosOne $(n=403)$ \\
\hline & $\begin{array}{l}\text { JAMA Journal of TheAmericanMedicalAssociation } \\
(\mathrm{n}=378)\end{array}$ \\
\hline & New EnglandJournal of Medicine $(n=274)$ \\
\hline & International Journal of InfectiousDiseases $(n=268)$ \\
\hline & Critical Care $(n=265)$ \\
\hline & Substainability $(\mathrm{n}=250)$ \\
\hline
\end{tabular}


Table 2: Distribution of top 5 publicationstypes of studies on COVID-19 fromJanuary 1 toDecember 13, 2020 duetotheWoS

\begin{tabular}{|c|c|}
\hline \multirow{5}{*}{$\begin{array}{c}\text { Article } \\
(\mathrm{n}=21087) \\
(44.51 \%)\end{array}$} & USA $\quad(n=6297)$ \\
\hline & Peoples R China $\quad(n=4120)$ \\
\hline & Italy $(\mathrm{n}=2380)$ \\
\hline & England $(\mathrm{n}=1950)$ \\
\hline & Germany $(n=1187)$ \\
\hline \multirow{5}{*}{$\begin{array}{c}\begin{array}{c}\text { Letter } \\
(\mathrm{n}=9793) \\
(20.67 \%)\end{array}\end{array}$} & USA $\quad(n=2026)$ \\
\hline & Italy $(n=1520)$ \\
\hline & $\begin{array}{l}\text { Peoples R China } \quad(n=1239) \\
\end{array}$ \\
\hline & England $(\mathrm{n}=1095)$ \\
\hline & India $(n=641)$ \\
\hline \multirow{5}{*}{$\begin{array}{c}\text { Editorialmaterial } \\
(\mathrm{n}=8709) \\
(18.38 \%)\end{array}$} & USA $\quad(n=3426)$ \\
\hline & England $(\mathrm{n}=1130)$ \\
\hline & Italy $(\mathrm{n}=811)$ \\
\hline & Peoples R China $\quad(n=573)$ \\
\hline & Canada (494) \\
\hline \multirow{5}{*}{$\begin{array}{c}\text { Early Access } \\
(\mathrm{n}=5913) \\
(12.48 \%)\end{array}$} & USA $\quad(n=1535)$ \\
\hline & Italy $\quad(n=734)$ \\
\hline & Peoples R China $\quad(n=647)$ \\
\hline & England $(\mathrm{n}=581)$ \\
\hline & India $\quad(n=514)$ \\
\hline
\end{tabular}

Table 3:Distribution of top 5 countriesaccordingtothecontributionrates on COVID-19 studiesfromJanuary 1 toDecember 13, 2020 duetotheWoS

\begin{tabular}{|c|c|}
\hline \multirow{5}{*}{$\begin{array}{c}\text { USA } \\
(\mathrm{n}=13781) \\
(29.09 \%)\end{array}$} & Article $(\mathrm{n}=6297)$ \\
\hline & EditorialMaterial $(n=3426)$ \\
\hline & Letter $\quad(n=2026)$ \\
\hline & Early Access $\quad(n=1535)$ \\
\hline & Review $(\mathrm{n}=1518)$ \\
\hline \multirow{5}{*}{$\begin{array}{c}\text { Peoples R China } \\
(\mathrm{n}=6884) \\
(14.53 \%)\end{array}$} & Article $(n=4120)$ \\
\hline & Letter $(n=1239)$ \\
\hline & Review $(\mathrm{n}=831)$ \\
\hline & Early Access $\quad(n=647)$ \\
\hline & EditorialMaterial $\quad(n=573)$ \\
\hline \multirow{5}{*}{$\begin{array}{c}\text { Italy } \\
(\mathrm{n}=5511) \\
(11.63 \%)\end{array}$} & Article $(n=2380)$ \\
\hline & Letter $(n=1520)$ \\
\hline & EditorialMaterial $\quad(n=811)$ \\
\hline & Early Access $\quad(n=734)$ \\
\hline & Review $(n=691)$ \\
\hline \multirow{5}{*}{$\begin{array}{l}\text { England } \\
(\mathrm{n}=4845) \\
(10.22 \%)\end{array}$} & Article $(\mathrm{n}=1950)$ \\
\hline & EditorialMaterial $\quad(n=1130)$ \\
\hline & Letter $\quad(n=1095)$ \\
\hline & Early Access $\quad(n=581)$ \\
\hline & Review $(n=567)$ \\
\hline \multirow{5}{*}{$\begin{array}{c}\text { India } \\
(\mathrm{n}=2398) \\
(5.06 \%)\end{array}$} & Article $(\mathrm{n}=1081)$ \\
\hline & Letter $(n=641)$ \\
\hline & Early Access $\quad(n=514)$ \\
\hline & Review $(\mathrm{n}=419)$ \\
\hline & EditorialMaterial $(\mathrm{n}=238)$ \\
\hline
\end{tabular}




\section{DISCUSSION}

This bibliometric study analyzed $n=47368$ publications' data related to COVID-19, that were published between January 1, 2020 to December 13,2020 and extracted from the WoS database. This is the largest sample of COVID-19 related papers analysis we encountered in the literature. The relevant bibliometric studies that analyzed worldwide data for COVID-19 were first had a relatively smaller time span and so they had smaller samples; second produced contradictionary results due to the analyze dates ${ }^{4}$.

Most of the publications are in English followed by Spanish and German. Chinese as a publication language ranked the ninth row according to our results. A bibliometric analysis reported that the most used language for publications in the early stages of the pandemic was English ${ }^{8}$. Contrary to this finding, another search stated that in the earliest stages of the epidemic, the number of articles published in Chinese was approximately 2.5 fold larger than the number of articles published in English ${ }^{3}$. This may be because China was the most severely affected country in early stages of pandemic ${ }^{3}$ and/or papers published in English acted as a barrier to the utilization of information in China ${ }^{7}$. On the other hand, in another study (on March 1th, 2020 the date of study), the authors stated that publications in English were also reported by Chinese authors. They preferred English as a language to share knowledge internationally. However, since English publications could not be written properly according to grammar in every region of China; in some regions of China, Chinese authors preferred to wrote the reports in Chinese ${ }^{7}$.

"Medicine General Internal"publicationsarethe highest in thelist of Web of Sciencecategories, followedby "PublicEnvironmentalOccupationalHe alth" and "InfectiousDiseases". Accordingtoour study "Anonymous authors" ranked the first row on the list of authors. Although "Anonymous authors" ranked the first row, a remarkable number of authors are identified. Eight author published over 150 papers. Wang Y was found as the leading researcher with 207 publications. According to our study results, all authors with over 150 publications were from China.

The "British MedicalJournal" is theleading journalthatpublishedthe COVID-19 related researches. It is followedbyJournal of "MedicalVirology", "International Journal of EnvironmentalResearch" and "PublicHealth". Most of thepaperswerepublished in journalsthathavehighimpactfactor ${ }^{6}$.
Article is on the top with the highest publications followed by letter and editorial material. Previous publications had also reported conflicting results on this issue. While some reported that article was the highest publication type; some reported the reviews was the the highest publication type ${ }^{3}$. Our previous analysis that compared first quarter with first half of the year for COVID-19 reported that editorial material and article were top type of publications respectively ${ }^{9}$.

USA is the most contributed country to the publications on COVID-19 according to our analysis. It is followed by PRC, Italy, England and India. But in the early phase of the pandemic PRC rank the first raw with published articles. USA ranked second row. Japan and European countries such as United Kingdom, Germany and Italy followed these countries ${ }^{1,3,8}$. In a study, authors stated that journal publications on COVID-19 suggested scientists to collaborate and launch the joint research projects. So China has collaborated with 21 countries including US, Canada, Japan, Europe and Southeast Asia ${ }^{3}$. According to reports in the literature, China had thickest cooperation with USA 6,7 which is consistent with the publications retrieved from the database ${ }^{7}$. The probable explanations for this cooperation are having superior conditions for basic medical research and experimental trials including economic resources, advanced equipment and skilled researchers ${ }^{6,7}$. On the other hand, it may be due to positive correlation with the production rate of the countries and their casualties inflicted by the pandemic as the publications hypothesized ${ }^{4,6}$.

Limitations of the study are 1)"Anonymous authors" ranked the first row on the list of authors, 2. WoS software versioncannotanalysis citationsfornumber of publicationsoverthan 10.000. ${ }^{9}$ 3) Additionally, thefactthatonly SCI-E publicationswereinvestigated in thisstudy can be considered as anotherlimitation.

\section{CONCLUSION}

The present analyse reports an overview of the literature on COVID-19 since the beginning. These kind of periodic analysis provides interesting insights regarding the past and progress of each area of scientific knowledge and also can guide the rethinking of scientific data.

\section{REFERENCES}

1. Gautam P, Maheshwari S, Kaushal-Deep SM, Bhat AR, Jaggi CK. COVID-19: A Bibliometric Analysis andInsights. International Journal of 
Mathematical, Engineeringand Management Sciences 2020;5(6):1156-1169

2. Gallegos M, Cervigni M, Consoli AJ, CaychoRodriguez T, Polanco FA, Martino P, Pecanha VC, Videla CB, Polanco-Carrasco R, Cusinato AM. COVID-19 in Latin America: A Bibliometric Analysis of Scientific Publications in Health. Electronic Journal of General Medicine2020, 17(6), em261

3. Gong Y, Ma T, Xu Y, Yang R, Gao L, Wu S, Li J, Yue M, Liang $H$, He $X$, Yun $T$. EarlyResearch on COVID-19: A Bibliometric Analysis. CellPress Partner JournalTheInnovation 1, 100027, 2020. https://doi.org/10.1016/j. xinn.2020.100027

4.Al-Zaman S. Bibliometricanalysis of COVID-19 literature.https://doi.org/10.1101/2020.07.15.2015 4989

5. ElHawary H, Salimi A, Diab N, Smith L. Bibliometric Analysis of Early COVID-19 Research: The Top 50 CitedPapers. Infectious Diseases: ResearchandTreatment 2020;13:1-5

6. Zyoud SH, Al-Jabi SW. Mappingthesituation of research on coronavirus disease-19 (COVID-19):

a preliminarybibliometric analysis duringthe earlystage of theoutbreak. BMC Infectious Diseases2020;20:561

7. Fan J, Gao Y, Zhao N, Dai R, Zhang H, Feng $X$, Shi G, Tian J, Chen C, Hambly BD andBao S. Bibliometric Analysis on COVID-19: A Comparison of ResearchBetween English andChineseStudies. Front. PublicHealth 2020;8:477

Aristovnik A, Ravšelj D, Umek L. A Bibliometric Analysis of COVID-19 acrossScience andSocial ScienceResearchLandscape.

Doi:10.20944/preprints202006.0299.v1

8. Lou J, Tian SJ, Niu SM, Kang XQ, Lian HX, Zhang LX, Zhang JJ. Coronavirusdisease 2019: a bibliometricanalysisandreview.

EuropeanReviewforMedicalandPharmacologicalS ciences 2020;24:3411-3421

9. Bas K, Y1lmaz F. An evidence of sharpincrease of scientificproductivity on COVID-19 bycomparingpublications of thefirstquarterwith thefirsthalf of 2020. Erciyes Med J. Ahead of Print: EMJ-06882 | DOI: 10.14744/ etd.2020. 06882 